\title{
Spying is getting out of hand
}

\section{State Department allegations of Soviet surveillance in Moscow will cause much more trouble than the technique can have been worth. The time has come to agree a code of conduct for spies.}

Just as science fiction has a tendency to become fact, the literary genre of the spy thriller is turning into a curious kind of reality. So much is clear from the US State Department's claim last week that the members of its embassy's staff in Moscow have been contaminated with a chemical (nitrophenylpentadiene) which can be made to be fluorescent by irradiation in the ultraviolet. The allegation, on which further details are promised, is that the material has been planted in people's clothing and on, say, the steering wheels of motor cars in such a way that drivers' hands are likely to be contaminated. The announcement lends credence to the idea that, by means like this, it would be possible for Soviet security authorities to learn what members of the US embassy are about during the course of their working day.

There are several things to say, of which the first is that such a practice would be a serious infringement of the rules that should govern the conduct of diplomatic missions, laid down by the Vienna conventions on the subject. The principle is (or should be) that even people who work as diplomats in foreign countries are, like their hosts, entitled to a measure of personal privacy and to the presumption that they are not criminals - unless evidence to the contrary comes to light. That is why the agreements governing the conduct of embassies usually allow for people's freedom to travel within a certain well-defined area, and entail the assumption that meetings with local residents are by definition innocent unless discovered to be otherwise. A little reflection will show that the whole business of international diplomacy would grind quickly to a halt if these assumptions were not valid. Seeking to provide continuing surveillance of what foreign diplomats are up to, as the Soviet Union may have been doing, would be a serious breach of these important principles.

But even if the allegations are borne out by further evidence, what in principle will have been accomplished? The use of chemicals fluorescent in the ultraviolet has a minor place in forensic science as a means of marking objects whose origin is known, but a more conspicuous place in the luxuriant detectivestory literature of the West. The obvious difficulty, in the scheme the Soviet authorities are said to have used to track the movements of members of the US embassy in Moscow, is that there is no obvious way in which generalized use of the fluorescent chemical could possibly have been of value to them. It is unthinkable that the authorities could have scoured Moscow with ultraviolet lamps, looking for traces of US diplomats whose clothing had been doped with the tracking chemical. What would be possible is to tell whether some otherwise unknown person seen seated in some public place had been a US diplomat, or whether a particular high-denomination currency bill (a dollar or a rouble) had been peeled off a stack of notes by a person carrying the tell-tale chemical on his fingers. In other words, if such a chemical has been used and has been found

\section{Biological manuscripts}

Contributors are reminded that, with the transfer of the Biological Sciences Editor to the Washington office, they should in future send four copies of all manuscripts offered for publication either (as at present) to London or to Washington. useful by Soviet counter-intelligence authorities, it is more likely that its function has been to help tell what Soviet citizens have been doing than to keep a permanent watch on the movements of US diplomats. But the chances are that a technique like this would have been of only marginal value in the legitimate prosecution of counter-intelligence by the Soviet authorities. If real, the allegations probably point to some over-zealous and impracticable scheme suggested by an over-enthusiastic committee.

Even if diplomats elsewhere are unlikely to be exposed to hazards of this kind, because other police authorities are unlikely to copy the bizarre technique now described, there is not much else that is cheerful at this stage. If the details of the allegation are borne out, they are bound to sour the climate in which the Soviet Union and the United States approach the next few critical months of conversation about arms control, and about their general relationship with each other. That is the opposite of good news. In the United States, thrown into anxiety about national security by recent cases of espionage and by fears that foreign nationals, diplomats and others increasingly function as espionage agents, the result of the disclosures from the Moscow embassy may be to amplify still further the demand for extra restrictions on the movement of people away from the places to which they are formally posted. And the result of that would be a further twist in the depressing game of tit-for-tat that has characterized the relationship between the Soviet Union and the United States for too long now.

So, in a sense, the best hope is that the allegations now made by the State Department turn out to be untrue, or that while the details may be verified, the implication that chemicals have been used as a means of keeping track of diplomats may be mistaken. Unhappily, that is unlikely to be the case. But there is a chance that the Soviet leadership will be able to argue, with reasons given, that any such practices were carried out without its knowledge, perhaps by junior people in some over-eager part of its establishment. Even that would be a great deal to ask for; the Soviet Union has never been happy to confess to imperfections in its way of running its own affairs. Yet this, it seems probable, will be the only escape the government of France will have from the allegations in New Zealand that French agents were somehow involved with the sinking of the Greenpeace vessel at the end of June.

Espionage and its elaborations (sinking ships, assassinating people) may seem to governments necessary to their domestic security but they are also a threat to international security. Is it entirely unthinkable that they should be regulated by international treaty? The obvious difficulty is that all governments engage in espionage but insist that their hands are clean. That is increasingly a sick joke. Moreover, there are at least some circumstances in which the reality of espionage is acknowledged, as when governments trade groups of captured agents at the Berlin Wall or elsewhere. Why not go the obvious step further, and negotiate a kind of code of conduct for intelligence services. An agreement not to take direct action against third parties (such as Greenpeace) would not, after all, constitute an admission that other less foolish practices are matters of routine. President Reagan and Mr Gorbachev might usefully spend a few minutes on the topic at their meeting in November. 